\title{
4. Tackling the global education crisis: the UBS Optimus Foundation's use of social finance
}

\author{
Maya Ziswiler and Arushi Terway
}

\section{INTRODUCTION}

Around 264 million children and adolescents are not in school, and only one in 12 young people in low-income countries is on track to gain secondary level skills (UNESCO, 2017). Some progress in achieving gender equality has been made, but far more girls than boys still do not have access to an education (UNESCO, 2015). More alarmingly, estimates show that more than 617 million children and adolescents are not achieving minimum proficiency levels in reading and mathematics (UNESCO Institute of Statistics, 2017).

Warning of a learning crisis in global education, the recent World Development Report noted:

This learning crisis is a moral crisis. When delivered well, education cures a host of societal ills. For individuals, it promotes employment, earnings, health, and poverty reduction. For societies, it spurs innovation, strengthens institutions, and fosters social cohesion. But these benefits depend largely on learning. Schooling without learning is a wasted opportunity. More than that, it is a great injustice: the children whom society is failing most are the ones who most need a good education to succeed in life. (World Bank, 2018, p.3)

Especially of concern is the need for almost tripling the current education funding to meet the targets set out in the Sustainable Development Goal (SDG) 4 on Quality Education. The International Commission on Financing Global Education Opportunity (2016) estimates that low- and middle-income countries will be required to almost triple their domestic public expenditure on education from the current USD 1 trillion per year to USD 2.7 trillion by 2030 while also ensuring that the financial resources are utilised more effectively. Public spending on education by national governments falls short, with the global average of 14.1 per cent of total public expenditure allocated to education in 2015, which is lower than the global recommendation of 15 per cent to 20 per cent (UNESCO, 2017). Moreover, 
international aid to education has decreased over the last few years, from 10 per cent of overall development aid in 2009 to 6.9 per cent in 2015 .

There is increasing recognition globally that achieving the SDGs cannot succeed without the involvement of private investment capital - the current value of global capital markets is estimated at USD 218 trillion (United Nations Conference on Trade and Development, 2014). Social finance, an approach to mobilising private capital for social development, can contribute to increasing both financing and innovation in order to improve learning outcomes in the field of education. Social financing vehicles can help bridge the gap between the funding that is available and the funding that is required to reach the SDGs. Social finance, in combination with traditional funding flows, potentially offers a sustainable way of supporting progress and creating the conditions to affect the generational change needed to reframe the future for millions.

This chapter presents the UBS Optimus Foundation's approach to social finance in the education sector, along with existing initiatives and programmes that the Foundation is supporting. The UBS Optimus Foundation's social finance model aims to bring private capital funding into the education sector where it can potentially catalyse innovation and tackle some of its complex problems.

\section{THE ROLE OF SOCIAL FINANCE}

In the last two decades, social finance has gained prominence, primarily in the form of micro-finance credits and environmental projects (like 'green bonds'). More recently, the number of actors, types of instruments and kinds of projects in the social finance space have expanded. At the moment, social finance includes diverse approaches, models, mechanisms and instruments. In Europe alone, the social finance market reached around USD 21 billion in 2013 with France, Italy, Germany, the Netherlands and the United Kingdom representing the leading markets (Rizzi, Pellegrini \& Battaglia, 2018).

Social finance can be generally defined as:

Actively deploying private capital (whether investor or philanthropic funds), sometimes in combination with government funding, in business or funds that address a specified social need. The social finance investments primarily yield a positive social or environmental return and secondly a financial return (adapted from Fetherston, 2014; Geobey, Westley \& Weber, 2012).

However, social finance is not just about the additional funding for social projects: 
It is conceived as an ethos about the way money is used. . . social finance can be seen as the discourse around such flows that is developing in concrete terms in the new institutions of supply, intermediation, and demand. This is a discourse in flux with competing perspectives driving the debate. (Nicholls \& Pharoah, 2007 as cited in Moore, Westley \& Nicholls, 2012, p. 116)

The benefits of social finance are perceived on at least two fronts: (1) stimulation of innovation as it creates the space for experimentation that challenges the existing institutional logics and financial flows that are born by the dominant social structures and (2) support for social entrepreneurship and innovation by financing the project life cycle of development, adoption, implementation and scaling up (Moore et al., 2012; Nicholls, 2010).

Most social finance approaches engage a diverse set of stakeholders, who are attracted to the mechanisms for varying reasons. Each stakeholder plays an interconnected role in operationalising social financing, as demonstrated in Figure 4.1. Social enterprises that generate both financial and social value are attracted to these financial instruments because they often face difficulties in accessing mainstream capital due to the risk and return characteristics related to their businesses. For social investors, charities and philanthropies, which are seeking innovative models that maximise social return on investment, social financing instruments often provide rigorously documented achievement against clearly defined metrics (Fetherston, 2014; Nicholls, 2010). Governments are attracted to social finance instruments as they have the potential to tackle the challenging social problems with new sources of funding, without unpopular increases in taxation (Fetherston, 2014). Finally, mainstream investors see the opportunity for new initiatives to include corporate social responsibility and diversify their portfolios (Rizzi et al., 2018).

What social finance mechanisms share is the use of private capital to invest in a social enterprise that would otherwise have difficulty obtaining funding. With the investment tied to outcomes (ideally monitored by an external party), investors can achieve social impact. In addition, with a government or philanthropic entity ultimately paying for the social outcomes, investors can also potentially receive a financial return, while the government or philanthropy is able to defer payment until specific outcomes are reached. More specific examples of social finance vehicles will be discussed in the next section. 


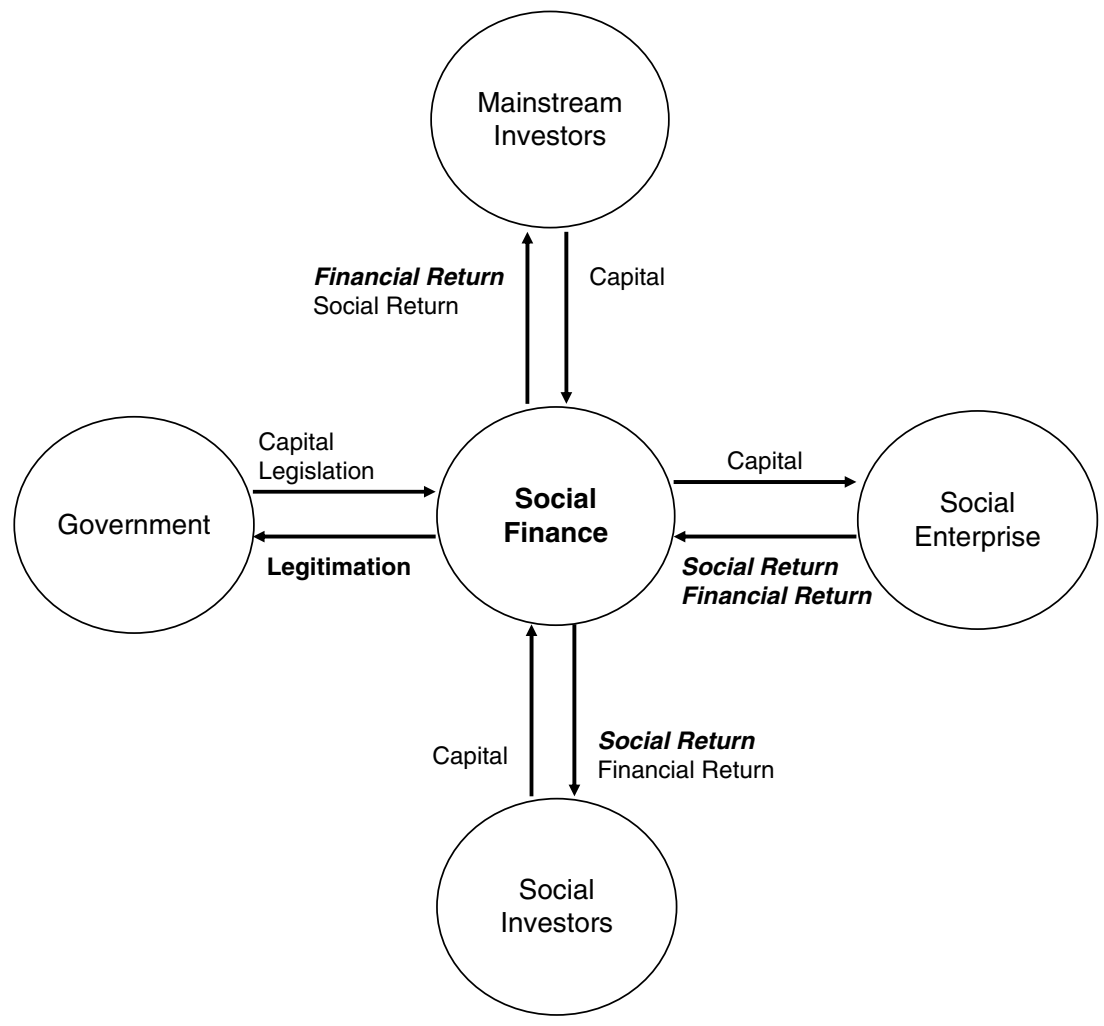

Source: Adapted from Rizzi et al. (2018).

Figure 4.1 Main categories of actors in social finance

\section{UBS OPTIMUS FOUNDATION'S APPROACH TO SOCIAL FINANCE}

UBS Optimus Foundation is a philanthropic foundation funded by UBS, ${ }^{1}$ its employees and its clients, focused on improving the lives of vulnerable children around the world. For over 15 years the Foundation has been finding and supporting innovative philanthropic programmes that can deliver

1 UBS is a Swiss multinational investment bank and financial services company founded and based in Switzerland. UBS works with private clients, institutions and corporations around the world, providing wealth management advice, investment banking and asset management expertise or general banking advice in Switzerland. 
bold social outcomes. With social finance approaches, the Foundation aims to rapidly accelerate the scale of successful programmes. Designed to utilise private capital to complement and supplement, rather than replace, existing funding from governments and NGOs, social finance offers a sustainable way of supporting progress and creating the conditions to affect the generational change needed to reframe the future for millions.

The Foundation sees three stages to the effective use of social finance: (1) building the proper ecosystem, (2) expanding programmes through the use of social finance mechanisms such as an impact loan or bond and (3) achieving long-term sustainable funding.

\section{Stage 1: Building the Ecosystem}

During the first stage of building the ecosystem for social finance, the Foundation uses philanthropic grant-making to support initiatives that have the potential to eventually attract private capital. Initial grant support includes things like building local capacity via technical assistance, enabling the sharing of market knowledge and best practices, promoting complementary business models and conditions needed to shape policy and regulatory reform and providing grant-making support to accelerator organisations. The following programme is an example of a first-stage education-related programme the Foundation is supporting.

\section{Liberian Education Advancement Program (LEAP)}

In Liberia, the global downturn in commodity prices, which hit investment in public services hard, together with the effects of civil war and the Ebola crisis has led to some of the worst education indicators in the world. According to the Liberian government, only 20 per cent of children complete grade 12, and UNICEF has found that 62 per cent of young women and 36 per cent of young men aged 15 to 24 are illiterate (UNICEF, 2013). The Liberian Government has a vision to change this through bold and progressive education reforms. However, in recognition of its limited capacity, the Ministry of Education is looking to the nonstate sector to insource much needed school management expertise into the public system. Part of a wider set of education sector reforms set out in Liberia's Education Sector Plan, LEAP is a government-led public-private partnership pilot initiative targeting improvements for 50,000 children in 194 primary schools.

The Foundation is supporting this initiative with the idea that by getting learning outcomes right in a small number of schools, the lessons learned can be used to scale up. Separating the financing of education from its provision can improve learning outcomes by harnessing the entrepreneurial 
energy and expertise of non-state providers to focus on delivery, while the government focuses on regulation and quality assurance. Although these schools are now privately managed, all commissioning decisions, quality assurance and regulation remain the responsibility of the Ministry of Education, and all schools remain free of charge to the students.

The three-year randomised control trial, conducted by an independent entity, shows encouraging preliminary (year-one) results (Romero, Sandefur \& Sandholtz, 2017). Students in LEAP schools learned 60 per cent more than the students in non-LEAP schools, student attendance improved by 10 per cent and teachers were 20 per cent more likely to be in school than their counterparts elsewhere. Teachers in LEAP schools were 16 percentage points more likely to be engaged in active classroom instruction than the teachers in non-LEAP schools. Also, equally as important, students were more likely to think school was useful and were more understanding of people from different backgrounds. However, the evaluation also showed that the costs for these schools were high and some flexibility in the intervention design may be skewing the results. Evaluation of the entirety of the programme is still needed to establish the programme results.

The goal is for the long-term cost of LEAP to be equal to what many governments in the region already spend on their schools while creating exceptional educational outcomes. Regulating private providers so they focus on equity is important, as is ensuring existing schools remain free and non-selective. Plus, mechanisms like LEAP incentivise operators to move into previously neglected, remote and disadvantaged communities.

In the end, the Foundation envisions LEAP operators' costs will be funded by larger donors or the government. To enable this transition, it is exploring (with Social Finance UK) social finance options such as development impact bonds (discussed in the next section), which could provide needed financing upfront, with the ultimate goal of having larger donors or government take over the cost for outcomes.

\section{Stage 2: Scaling Up with Social Finance}

At the second stage, social finance mechanisms are designed to attract new and much needed sources of funding, promote an impact-first mindset to deliver maximum social outcomes and contribute towards achieving the ambitious SDGs. Mechanisms currently being employed, and discussed here, include impact loans and development impact bonds. Both have the ability to bring in private capital, thereby multiplying the impact of philanthropic donations in certain situations where funding is needed as a bridge to longer-term sustainability. 


\section{Impact loans}

Impact loans are for social businesses that can achieve impact targeting low-income beneficiaries who can pay for some products and services. Promising social enterprises that need loans to grow are encouraged to achieve impact targets by tying such targets to lower loan costs. Impact loans can reconcile the tensions between the financial requirements of investors and the impact motivations of social entrepreneurs: when a social enterprise needs a loan to grow, a social investor provides a concessionary loan, with interest rates that are lower than the market rates but linked to social impact targets. Independent verification confirms that targeted outcomes are achieved and the social enterprise then pays interest proportional to the impact achieved.

One kind of impact loan (see Figure 4.2) includes a philanthropic donor (the outcome payer) who pays an extra return to investors for every outcome achieved (outcomes that would not have been possible without the impact loan). For the social investors, achieving impact targets correspondingly results not only in higher social returns but also in a higher financial return.

Impact loans address a timing mismatch with respect to financing. They allow social enterprises to use social investment to fund immediate capital requirements to support, sustain and grow the enterprise - thus, in theory, creating more impact. The simple contracting structure aligns the interests of social investors, social enterprises and philanthropic outcome payers to

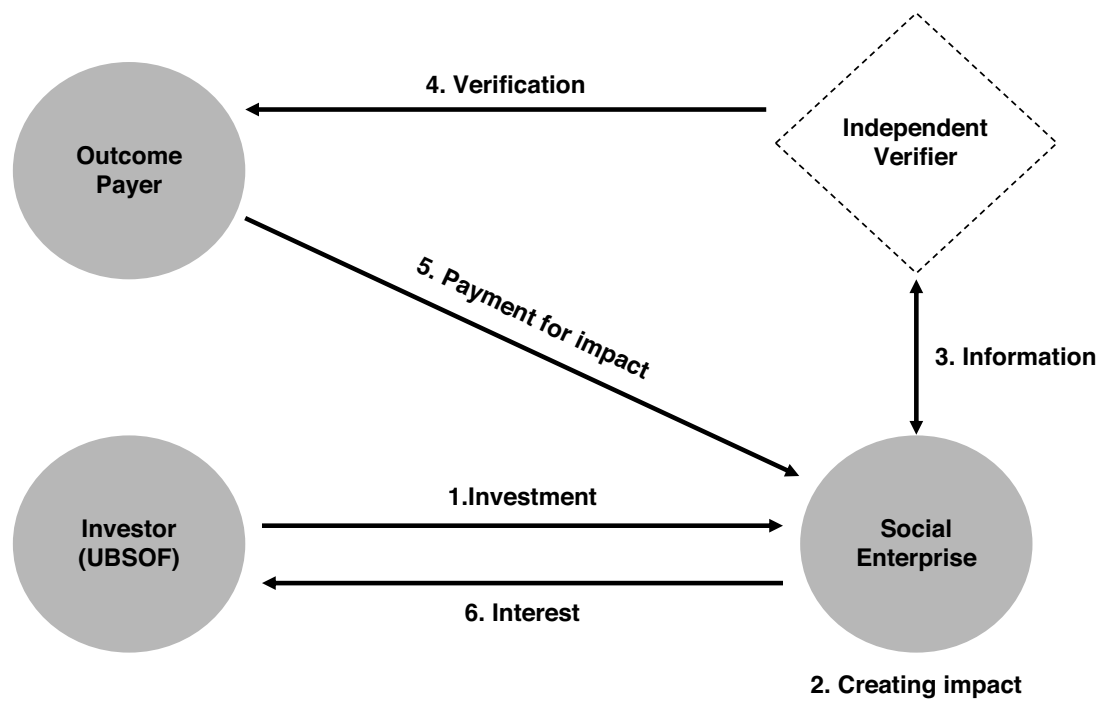

Figure 4.2 Impact loan structure 
achieve a financial return with measurable social impact: investors receive a risk-adjusted return; social enterprises access low-cost capital, allowing them to focus on social impact without the pressure of offering market-rate financial returns; and the outcome payers achieve far greater leverage for their philanthropic dollars to achieve social impact. The following example illustrates how impact loans function.

Impact Water Uganda (IWU) impact loan According to UNICEF (2010), more than 40 per cent of diarrhoea cases in schoolchildren result from transmission in schools rather than homes. Clean drinking water in schools is essential if students are to stay healthy and be able to learn. One barrier to installation of clean water systems at schools is the need for financing, a problem that hinders access to clean drinking water globally (WHO \& UN-Water, 2017).

IWU is a social business dedicated to scaling safe drinking water solutions for schools and health facilities in Uganda. IWU typically provides financing to private schools over a period of one to two years with five payment terms aligned with school terms, allowing schools to offer clean water while paying off their loan when they receive school fees. The Foundation is supporting the accelerated rollout of IWU's water systems with a USD 500,000 five-year loan. IWU aims to sell and install 3,600 systems in five years with an average of 400 beneficiaries per system, equalling over 1.4 million beneficiaries in total. The World Health Organization estimates such improvements can reduce absenteeism by three days per student (Hutton \& Haller, 2004).

The Foundation will receive a return on its impact loan to IWU that could rise to approximately eight per cent if all targets are met, as the Rockefeller Foundation will pay an outcome payment depending on IWU's ability to meet impact targets. Any surplus created through this programme will be used to support future UBS Optimus Foundation programmes. Through this simple structure, IWU is incentivised to maximise its impact to obtain low-cost capital. At the same time, the UBS Optimus Foundation, as the investor, bears the risk and is motivated to ensure IWU achieves its targets. Finally, the Rockefeller Foundation is able to multiply the impact of its philanthropic funding by incentivising up-front investment and paying only based on results.

\section{Development impact bonds (DIBs)}

DIBs are another example of a results-based social finance instrument (see Figure 4.3). They seek to mobilise additional private capital by driving greater impact through payment linked solely to results, thereby channelling more resources to programmes that work. DIBs have the potential to 


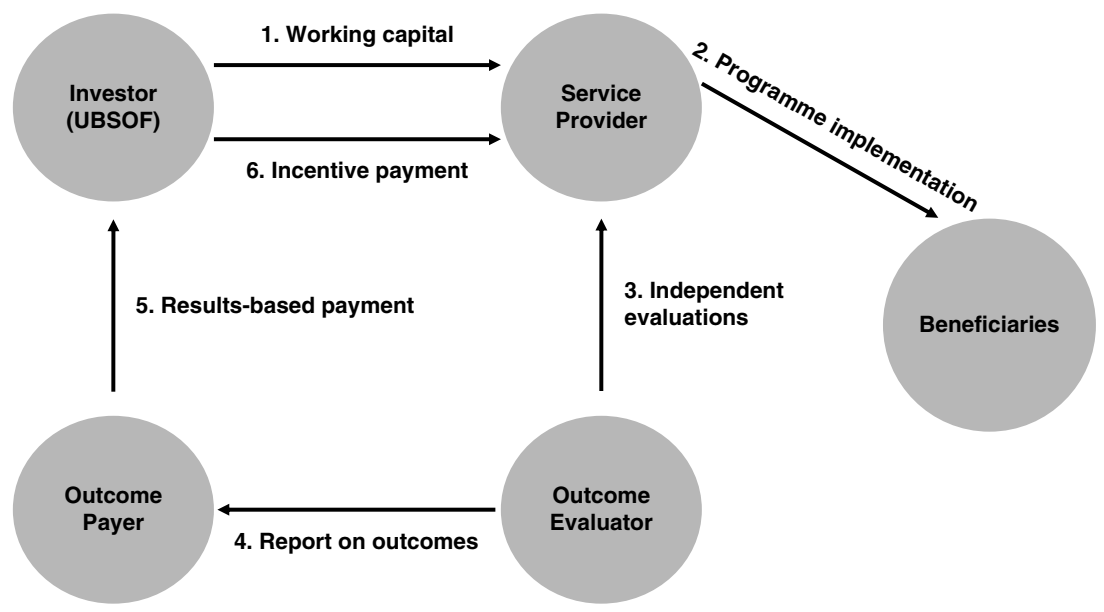

Figure 4.3 The development impact bond structure

create shared value in a variety of ways: underserved communities receive social benefits; service providers are given flexibility in implementation; governments and donors get increased efficiency, value for money and accountability; and investors have the opportunity for results-based financial returns.

In a DIB, an investor pays upfront for the costs of an intervention, which is then measured by clear, predetermined metrics. If the intervention succeeds in achieving its goals, the outcome payer will pay the investor back based on the performance. The initial capital plus the performance-related return is returned to the investor, who can then re-invest into subsequent impactful programmes. In addition, a portion of the success payment is passed on to the service provider as an incentive.

A number of criteria must be met for DIBs to be feasible and successful. A simple, cost-effective financing structure must minimise perverse incentives. There must be close cooperation between partners, including strong buy-in from relevant governments and key donors. The freedom to use adaptive programming must be built in for efficiency and improved performance. Any impact deemed achieved, and ensuing payments, must be supported by independently validated evidence. Finally, the intervention needs to be scalable and able to eventually become sustainable.

According to the Social Finance Global Network, there are currently over 100 impact bonds globally that have together raised USD 378 million and impacted 700,000 lives. However, the vast majority of them have been 
implemented in the United Kingdom and the United States. The UBS Optimus Foundation is a pioneer in developing and implementing DIB structures in low- and middle-income countries (Chandrasekhar, 2018). The following example illustrates how a DIB can be used to advance education.

Educate Girls DIB In India, three million girls are out of school (Social \& Rural Research Institute, India \& Educational Consultants India Limited, 2014) and less than half the girls of senior secondary age (grades 11 and 12) are enrolled in schools (Rao, 2017). Yet, we know that educating girls helps break the cycle of poverty. Each year that a girl attends school can increase her future earnings by 10 per cent to 25 per cent (UNICEF, 2011). Educated women are less likely to marry early (and against their will), less likely to die in childbirth, more likely to have fewer and healthier children, more likely to send their own children to school and more likely to play an active role as leaders in their communities (UNICEF, 2011).

Educate Girls works with government and communities to enrol girls in school while improving school infrastructure and the quality of education they receive. It recruits community volunteers to help the community understand the importance of educating girls. By involving the community in school management and governance, parents and others can see the benefit of a creative, child-centric curriculum - and the improved learning outcomes.

Educate Girls, the UBS Optimus Foundation and Children's Investment Fund Foundation (CIFF) launched the world's first DIB in education in 2015. The three-year pilot aimed to improve education for 7,300 children in 166 schools in 140 villages in the Bhilwara District of Rajasthan. This site was chosen as it had particularly poor indicators for girls' education. The targets were to enrol 79 per cent of out-of-school girls and improve learning as measured by Annual Status of Education Report (ASER) test scores in Hindi, mathematics and English for girls and boys.

Year-three results of the DIB show that Educate Girls exceeded both its enrolment and learning targets. It achieved 116 per cent of the enrolment target and 160 per cent of the learning target in its final year. The results show that 92 per cent of all out-of-school girls identified in the programme area were enrolled in school, while the difference in learning gains was $+8,940$ ASER learning levels above - or 28 per cent higher than - the control group gains (IDinsight, 2018).

As a result of the over-achievement, the Foundation recouped its initial funding (USD 270,000) plus a 15 per cent internal rate of return, which equals USD 144,085, from the outcome payer CIFF. The total payout will be reinvested into further impactful development programmes-Educate 
Girls will receive 32 per cent of the internal rate of return with the rest going to other Foundation programmes.

The Educate Girls DIB has demonstrated the potential to attract much needed funding for education as donors are increasingly seeing that they can achieve real social impact and results-based financial returns. With payments to both investor and provider tied to outcomes, the DIB creates the right incentives for a focus on impact rather than activities.

\section{Stage 3: Long-term Sustainable Funding}

Maximising social impact that is sustainable in the long term is the ultimate aim of the Foundation's work with two long-term sustainable sources for funding: public funding and private (or hybrid) funding. Programmes supported by a DIB can be shifted to receive support through social impact bonds. ${ }^{2}$ Or, after a programme has demonstrated success with the help of social finance, it can be moved into the public sector. Programmes or social enterprises may become commercially viable and then such enterprises may be appropriate for impact investments. A hybrid approach utilises both philanthropic and fully commercial capital, and the Foundation is currently exploring such models.

Impact bonds are promising new financing instruments that draw on the experiences of public-private partnerships, impact investing and results-based financing. Yet, despite the promise, impact bonds have been relatively slow to gain traction in international development. To date, only a handful of impact bonds are in operation in low- or middle-income countries (Gustafsson-Wright \& Boggild-Jones, 2018; Instiglio, 2018). In order to accelerate the number, scale and quality of impact bonds in international development, the Foundation, along with the United Kingdom's Department for International Development (DfID) and the Swiss State Secretariat for Economic Affairs (SECO), has launched the Impact Bonds Working Group (IBWG). IBWG aims to design strategies that will help members use impact bonds and related pay-for-success instruments effectively and at scale, thereby improving the quality and impact of development projects and contributing to meeting the SDGs.

The IBWG will aim to launch a portfolio of Demonstration Outcomes Funds, with an initial target of USD 150 million in funding committed by 2020 to fund outcomes-based transactions across approximately three demonstration outcomes funds. The portfolio of outcomes funds supported through this market strategy will help demonstrate how outcomes-

2 A Social Impact Bond (SIB) is structured similarly to a DIB; however, the outcome payer in a SIB is the government, while in a DIB it is a donor. 
based commissioning can be done at a larger scale and how transaction costs can be reduced, generating robust evidence on when and how to use pay-for-success instruments and their costs and benefits relative to other instruments. The approach will help transition the impact bond market from 'single pilot projects' to a 'programmatic approach in thematic areas', where commissioning design costs are spread across multiple transactions, thereby leading to lower transaction costs per project and accelerating a learning agenda for the broader market. IBWG will prioritise assessing existing outcome fund concepts currently under development in the market, with geographic (low- and middle-income countries) and thematic diversity (e.g., education, health, employment) (Kirchknopf, 2018).

The Foundation seeks to develop a parallel DIB Investment Fund with an aim to provide working capital for DIB programmes that triggers payments from a DIB Outcome Fund based on outcomes achieved. By pooling DIBs into a fund structure, the aim is to diversify risk, lower transaction costs and leverage expertise both on the impact and on the financial sides. Blending different types of investor capital will enable the demand for a reasonable return from the outcome funders, balancing more market-based returns and scale for impact investors with capital preservation and social returns for social investors.

\section{THE CHALLENGES WITH SOCIAL FINANCE IN EDUCATION}

Traditional aid for education is under pressure (Rose, Steer, Smith \& Zubairi, 2013). If we are to achieve the SDGs for education, the private sector has an essential role to play in developing and funding innovative solutions. Social finance mechanisms can play a role, but there are some hurdles.

Social finance mechanisms, such as impact loans or DIBs, are not the silver bullet for solving all funding and impact problems in the development or education sectors. These financing instruments have the potential to 'address complex problems with a clear outcome where there is a need for innovation, external capital, and new collaborations and partnerships' (Toby Eccles as cited in Chandrasekhar, 2018, para. 13). As the problems get more complex, designing social finance programmes where outcomes can be clearly linked to the intervention (as opposed to other contextual factors) becomes challenging. Social finance approaches require programmes and interventions that have an explicit and unambiguous theory of change and can demonstrate measurable outcomes (Moore et al., 2012).

With results from the first DIB in education, the Foundation is now able to move beyond this initial proof-of-concept stage. Lessons learned include 
the need for decreasing transaction costs and an increase in the size and scale of DIB transactions. This knowledge is already being applied to the new maternal and newborn health DIB, which the Foundation launched in November 2017 in Rajasthan, India, and a new education DIB, which is currently in the design stage. Other lessons learned include the need to match supply and demand in the impact bond market, build the capacity of service providers and develop structures to deal with financial regulatory constraints for various stakeholders involved. The Demonstration Outcomes Funds mentioned in the previous section will be a step towards tackling these constraints.

Social finance interventions funded by philanthropic organisations, including the ones funded by the UBS Optimus Foundation, often support non-state or private education providers. The Foundation is conscious of the debate about non-state actors in education (Steer, Gillard, GustafssonWright \& Latham, 2015), particularly in low-income countries, and we know this can present an obstacle in the acceptance and implementation of social financing models. However, as the Brookings Institution notes, private education is growing rapidly and effective new approaches to improving learning often originate from outside the public system (Robinson, Winthrop \& McGivney, 2016). Evidence suggests that private schools are of slightly better quality and more efficient than their public counterparts (Muralidharan \& Kremer, 2006; Tooley, Dixon \& Olaniyan, 2005), but there is concern that private schools are not reaching those most in need (Parliament, 2017).

Social finance approaches are particularly challenging in the education sector. Investors are deterred by the longer time frames required to improve education. These investors often also want simplicity, yet this is rarely the case with complex value chains involving the many different parts of an education system. There is also the fact that no universal agreement exists among experts on the best approaches, which may put off investors who want certainty.

Social finance is not a panacea, but in the right context it can help scale up promising initiatives and draw in expertise from a broad-and often previously disengaged - range of stakeholders. The challenges above need to be addressed if social finance is to truly fulfil its potential, and that will take time.

\section{LOOKING AHEAD}

UBS Optimus Foundation recognises that catalysing the use of social finance instruments in education will require input from many 
sources - philanthropists, investors, donors, as well as the private sector. Encouragingly, this is already happening as philanthropic donors are recognising the potential of co-creation and co-investment, while an increase in private sector finance in development has been identified as a key priority in achieving the SDGs.

Social finance mechanisms that combine the best of private-sector efficiency and financing, philanthropic programme support and impact measurement can create far more than the sum of their parts. Attracting additional private sector capital is crucial to help achieve the SDGs, but equally important is the combination of skills and networks new mechanisms can bring to the education development sector.

The use of social finance in low- and middle-income countries, especially in the education sector is still in the nascent phase. There is a need for developing an ecosystem to allow for experimentation with the different mechanisms outlined in this chapter. However, along with experimentation, there is also a critical need for research to better understand the efficacy of these mechanisms in improving education quality. While most social finance interventions have rigorous evaluation built into the design, there is need for external and independent research to understand the role of these mechanisms in fulfilling SDG 4. Further research could also help the education community better understand how these mechanisms work towards diversifying the funding sources for education along with the role of non-state actors in the provision of education.

This chapter makes a case for utilising social finance in the education sector to attract private capital and improve quality. In providing an introduction to the design of these financing mechanisms with examples of existing programmes, the authors hope to shed some light on how social finance engages with the education and private capital worlds. The authors hope that this will encourage practitioners and researchers in the education sector to examine these mechanisms further and help contribute to a more informed and evidence-based dialogue.

\section{REFERENCES}

Chandrasekhar, A. (2018). Switzerland: a hub for innovative social financing. Retrieved June 21, 2019, from https://www.swissinfo.ch/eng/business/impact-bon ds_switzerland--a-hub-for-innovative-social-financing/43871058

Fetherston, J. (2014). Social finance: Sorting the hope from the hype. Kennedy School Review, 14, 28.

Geobey, S., Westley, F. R., \& Weber, O. (2012). Enabling social innovation through developmental social finance. Journal of Social Entrepreneurship, 3(2), 151-165.

Gustafsson-Wright, E., \& Boggild-Jones, I. (2018). Paying for social outcomes: A 
review of the global impact bond market in 2017. Washington, DC: The Brookings Institution. Retrieved June 21, 2019, from https://www.brookings.edu/blog/edu cation-plus-development/2018/01/17/paying-for-social-outcomes-a-review-of-the -global-impact-bond-market-in-2017/

Hutton, G., \& Haller, L. (2004). Evaluation of the costs and benefits of water and sanitation improvements at the global level. Geneva, Switzerland: World Health Organization. Retrieved June 21, 2019, from http://www.who.int/water_sanitation _health/wsh0404.pdf

IDinsight. (2018). Educate Girls Development Impact Bond: Final evaluation report. New Delhi, India: Author. Retrieved June 21, 2019, from http://idinsight.org/ wp-content/uploads/2018/07/Educate-Girls-DIB-Final-Evaluation-Report_201806-10.pdf

Instiglio. (2018). Impact bonds worldwide. Retrieved June 21, 2019, from http:// www.instiglio.org/en/sibs-worldwide/

The International Commission on Financing Global Education Opportunity. (2016). The learning generation: Investing in education for a changing world. New York, NY: The Education Commission. Retrieved June 21, 2019, from http://report.educationcommission.org/wp-content/uploads/2016/09/Learning Generation_Full_Report.pdf

Kirchknopf, L. S. (2018). Impact Bonds Working Group [PowerPoint presentation]. Retrieved June 21, 2019, from https://www.enterprise-development.org/wpcontent/uploads/SECO-DCED-AM-2018.pdf

Moore, M.-L., Westley, F. R., \& Nicholls, A. (2012). The social finance and social innovation nexus. Journal of Social Entrepreneurship, 3(2), 115-132.

Muralidharan, K., \& Kremer, M. (2006). Public and private schools in rural India. Cambridge, MA: Harvard University, Department of Economics.

Nicholls, A. (2010). The institutionalization of social investment: The interplay of investment logics and investor rationalities. Journal of Social Entrepreneurship, 1(1), 70-100.

Parliament. (2017). DfID's work on education: Leaving no one behind. Retrieved June 21, 2019, from https://publications.parliament.uk/pa/cm201719/cmselect/ cmintdev/367/36702.htm

Rao, N. (2017). Vital stats overview of school education in India. New Delhi, India: PRS Legislative Research. Retrieved June 24, 2019 from https://www.prsindia. org/policy/vital-stats/overview-school-education-india

Rizzi, F., Pellegrini, C., \& Battaglia, M. (2018). The structuring of social finance: Emerging approaches for supporting environmentally and socially impactful projects. Journal of Cleaner Production, 170, 805-817.

Robinson, J. P., Winthrop, R., \& McGivney, E. (2016). Millions learning: Scaling up quality education in developing countries. Washington, DC: The Brookings Institution. Retrieved June 21, 2019, from https://www.brookings.edu/wp-con tent/uploads/2016/04/FINAL-Millions-Learning-Report-1.pdf

Romero, M., Sandefur, J., \& Sandholtz, W. A. (2017). Can outsourcing improve Liberia's schools? Preliminary results from year one of a three-year randomized evaluation of partnership schools for Liberia (Working Paper 462). Washington, DC: Center for Global Development. Retrieved June 21, 2019, from https:// www.poverty-action.org/sites/default/files/publications/partnership-schools-forliberia.pdf

Rose, P., Steer, L., Smith, K., \& Zubairi, A. (2013). Financing for global education opportunities for multilateral action. Washington, DC and Paris, France: The 
Center for Universal Education at the Brookings Institution and UNESCO. Retrieved June 21, 2019, from https://www.brookings.edu/research/financing-forglobal-education-opportunities-for-multilateral-action/

Social \& Rural Research Institute, India \& Educational Consultants India Limited. (2014). National sample survey of estimation of out-of-school-children. Noida, India: Educational Consultants India Limited. Retrieved June 21, 2019, from http://mhrd.gov.in/sites/upload_files/mhrd/files/upload_document/National-Sur vey-Estimation-School-Children-Draft-Report.pdf

Steer, L., Gillard, J., Gustafsson-Wright, E., \& Latham, M. (2015). Non-state actors in education in developing countries: A framing paper for discussion. Washington, DC: Center for Universal Education at Brookings Institution. Retrieved June 21, 2019, from https://www.brookings.edu/wp-content/uploads/2016/06/102215Non-State-Actors-in-Education-Framing-paper-Final.pdf

Tooley, J., Dixon, P., \& Olaniyan, O. (2005). Private and public schooling in low-income areas of Lagos State, Nigeria: A census and comparative survey. International Journal of Educational Research, 43(3), 125-146.

UNESCO. (2015). Education for all 2000-2015: Achievements and challenges. Paris, France: Author.

UNESCO. (2017). Accountability in education: Meeting out commitments. Paris, France: Author.

UNESCO Institute for Statistics. (2017). More than one-half of children and adolescents are not learning worldwide (Fact Sheet No. 46). Montreal, Quebec: Author. Retrieved June 21, 2019, from http://uis.unesco.org/sites/default/files/documents/ fs46-more-than-half-children-not-learning-en-2017.pdf

UNICEF. (2010). Raising clean hands: Call to action for WASH in Schools advocacy pack. New York, NY: Author. Retrieved June 21, 2019, from https://www. unicef.org/wash/schools/files/rch_cta_advocacypack_2010.pdf

UNICEF. (2011). UNICEF says education for women and girls a lifeline to development. Retrieved June 21, 2019, from https://www.unicef.org/media/media_58417. html

UNICEF. (2013). At a glance: Liberia. Retrieved November 18, 2018, from https:// www.unicef.org/infobycountry/liberia_statistics.html

United Nations Conference on Trade and Development. (2014). World investment report, 2014. Geneva, Switzerland: United Nations.

WHO, \& UN-Water. (2017). UN-Water global analysis and assessment of sanitation and drinking-water (GLAAS) 2017 report: Financing universal water, sanitation and hygiene under the sustainable development goals. Geneva, Switzerland: World Health Organization. Retrieved June 21, 2019, from http://apps.who.int/iris/bit stream/10665/254999/1/9789241512190-eng.pdf?ua=1

World Bank. (2018). World development report 2018: Learning to realize education's promise. Washington, DC: Author. 